\title{
A Study on Financial Analysis of Maruthi Suzuki India Limited Company
}

\author{
*Dr.A.Ramya, ${ }^{* *}$ Dr.S.Kavitha \\ * Assistant Professor, Department of B.COM (CA), Sankara College of Science and Commerce, Coimbatore-35 \\ ** Assistant Professor, Department of BBA (CA), Sankara College of Science and Commerce, Coimbatore-35
}

\begin{abstract}
Financial performance analysis is the process of determining the operation and financial characteristics of a firm from accounting and financial statements. The goal of such an analysis is to determine the efficiency and performance of the firm's management, as reflected in the financial records and reports. The study focus on overall financial position of particular Maruthi Suzuki company during the specific period based on the selected variables, which may interest not only for the respective companies in the industry but also brings a process of development operational aspects of the entire industry. The study is much important to the management from the point of decision-making purpose, to identify the strength, weakness areas of the company and finally helps to maximize the intrinsic value of the company.
\end{abstract}

\section{Introduction}

Every business organization, whether manufacturing oriented or service oriented, needs finance, i.e., money for carrying on its activities. Though business organization gets sufficient money for carrying its activities, success of the business depends on how well the organization manages them. That is, its depends on how well a business organization funds its capital and how efficiently it operates out of the invested capital to generate profit. While the success of the of a business also a subjective measure how well a firm can finance its assets and make use of the assets to generate revenues, the business can be stable and healthy if it is financial performance consistently yields profit. These measures often determine whether or not that level of performance is consider adequate. Further, a business organization is considered to be inefficient, if the performance level is often found to be low, even if it is making profit.

\subsection{FINANCIAL PERFORMANCE}

Financial performance analysis is the process of determining the operation and financial characteristics of a firm from accounting and financial statements. The goal of such an analysis is to determine the efficiency and performance of the firm's management, as reflected in the financial records and reports. The word 'performance' is derived from the word 'perfourmen', which means 'to do', or 'to carry out' or 'to tender'. It refers to the act of performing: execution, accomplishment, fulfillment etc. In a broader sense, performance refers to the accomplishment of a given task measured against preset standards of accuracy, completeness, cost and speed. Performance is used to indicate the firm's success, conditions, and complains. The goal of financial performance analysis is to determine the efficiency and performance of the firm's management, as reflected in the financial records and reports. The analyst attempts to measure the firm's solvency, liquidity, profitability and other indicators so that the business is conducted in a rational and normal way. More specifically, any research on financial performance of a business organization seeks to dwell upon mainly, (1) assessing the short term and long term solvency (2) assessing the liquidity and profitability, (3) identifying the efficiency of financial operations and (4) analyzing the factors determining the solvency level liquidity and profitability.

\subsection{NEED FOR THE STUDY}

The interest of the various groups related to a firm is affected by the financial performance of the firm. So it is much of significance for these groups to analyze the financial performance of the firm they are interested in. The study focus on overall financial position of particular Maruthi Suzuki company during the specific period based on the selected variables, which may interest not only for the respective companies in the industry but also brings a process of development operational aspects of the entire industry. The study is much important to the management from the point of decision-making purpose, to identify the strength, weakness areas of the company and finally helps to maximize the intrinsic value of the company. 


\subsection{STATEMENT OF THE PROBLEM}

Financial performance analysis is the process of determining the operation and financial characteristics of affirm from accounting and financial statements. The goal of such an analysis is to determine the efficiency and performance of the firm's management, as reflected in the financial records and reports. From the above point of view the researcher has undertaken an analysis of financial performance of Maruti Suzuki India Limited Company to understand how management of finance plays a crucial role in the growth.

\subsection{OBJECTIVES OF THE STUDY}

* To study the growth and development of Maruthi Suzuki India limited Company.

* To examine the consistency and growth rate of selected financial parameters of the particular Maruthi Suzuki Company

* To analyze profitability and liquidity status of the Maruthi Suzuki Company Limited.

\subsection{HYPOTHESES}

Null hypotheses was framed for the study.

\subsection{METHODOLOGY}

\subsubsection{SOURCES OF DATA}

Secondary data are used in this study, which were collected from the various data base, journal and magazines. Variables pertaining to behavior of liquidity, leverage and profitability were collected from the balance sheet and profit and loss account of the selected Maruthi Suzuki India Limited Company for a period of 5 years i.e from 2010-11 to2014-15.

\subsubsection{PERIOD OF THE STUDY}

The present study covers a period of five years from 2010-11 to 2014-15.

\subsubsection{FRAME WORK OF ANALYSIS}

Analyzing the performance of a company can be done through a carful and critical analysis of financial statements. The two important financial statements are 'Balance sheet" and 'Profit and loss account'. It indicates the operating results and financial position of the concern, therefore by analyzing and interoperating the statements, performance can be apprised. In the light of the above in this study various financial ratios and variables have been used to examine the objectives of the study.

\subsubsection{LIMITATIONS OF THE STUDY}

The study covers a period of five years from 2010-11 to 2014-15. Secondary data were collected for this study due to cost and time constrains. The present study is largely based on ratios, which have been its own limitations.

\subsubsection{CHAPTER SCHEME}

The present study is organized as six chapters

The first chapter covers introduction, significance of the study, statement of the problem, objective of the study, hypotheses framed, sources of data, period of the study, frame work of analysis, scope of the study, limitations of the study and scope for the further research. Review of literature are presented in the Second Chapter. The Third Chapter studies the history of the Maruthi Suzuki India Limited Company. The Fourth Chapter devoted for the financial analysis of the Mauthi Suzuki India Limited Company. Summary of findings, conclusions and suggestions are presented in the last chapter.

\subsection{Introduction}

\section{Rewiew Of Literature}

This chapter is aimed to reviewing research work relevant to Car Industries as well as articles in journals and earlier studies which focused on financial performance of companies under various industries.

Pradhan, Singh (2008) in recent years, developing countries have emerged as significant participants in the OFDI (Outward foreign direct investment) activities having the strategic asset seeking motive. Such OFDI which is assets exploiting cum augmenting involves potential two way cross border knowledge flows. This study examines these issues for the Indian automotive industry that is currently transnationalizing at a rapid rate in terms of both exports and OFDI. The study traces the technological capability building and several dimensions of OFDI in this industry. The case studies of two major automotive groups highlight their competence building and knowledge seeking operations. This study undertakes a quantitative analysis of the influence of OFDI activities on the in house (domestic) R\&D performance of Indian automotive firms during 1988-2008. As expected, the favorable impacts on R\&D intensity appear to be stronger for developed vs. 
developing host nations and for joint venture vs. wholly owned ownership OFDI. The study concludes with suggestions to promote particularly the strategic asset enhancing OFDI.

Sharma (2008) in her study on 'Indian Automotive Industry' has analyzed the sales and capabilities of different firms in automobile industry. The study further indicates that the growth in the automobile sector is expected to grow due to rising disposable income and increasing consumerism. The global automakers will continue to allocate a rising proportion of the foreign direct investment in India, growing auto-manufacturing first and latter auto engineering R\&D services. Many companies are aware of the fact that their labour cost advantage is beginning to erode as both shop floor and managerial wage costs rise. However, they are optimistic that productivity improvements through low cost automation and improved management efficiency will compensate to rising direct wage cost.

Kale (2011), in the last decade the Indian auto industry has shown increasing levels of technological sophistication and significant growth. The Indian auto industry consists of local firms with indigenous design and development capability, well established global brands and has marketing presence in Indian as well as other emerging markets. This paper tracks capability development in the Indian auto industry and seeks to understand the factors, both internal and external to firms that have shaped innovative capabilities. It points out that the Indian Government's industrial policy secured development of basic capabilities but restricted innovative capability development in auto manufacturing. This paper reveals that key attributes of firm ownership such as managerial vision and diversified nature of business, helped Indian firms in the development of the innovative capabilities.

Balakrishnan, Jagathy (2011) Globalization and liberalization, with the entry of many prominent foreign manufacturers, changed the automobile scenario in India, since early 1990s. Manufacturers such as Ford, General Motors, Honda, Toyota, Suzuki, Hyundai, Renault, Mitsubishi, Benz, BMW, Volkswagen and Nissan set up their manufacturing units in India in joint venture with their Indian counterpart companies by making use of the Foreign Direct Investment policy of the Government of India. These manufacturers started capturing the hearts of Indian car customers with their choice of technological and innovative product features, with quality and reliability. With the multiplicity of choices available to the Indian passenger car buyers, it drastically changed the way the car purchase scenario in India and particularly in the State of Kerala. This transformed the automobile scene from a sellers "market to buyers "market. Car customers started developing their own personal preferences and purchasing patterns, which were hitherto unknown in the Indian automobile segment. The main purpose of this paper is to come up with the identification of possible parameters and a framework development, that influence the consumer purchase behavior patterns of passenger car owners in the State of Kerala, so that further research could be done based on the framework and the identified parameters.

Ray (2012) ,this study tries to evaluate the performance of Indian automobile industry in terms of various financial indicators, sales trend, production trend, export trend etc. for the period of 2003-04 to200910.The result suggests that the automobile industry has been passing through turbulent phases characterized by enhanced debt burden, low utilization of assets, and above all, huge liquidity crunch .The key to success in the industry is to improve labour productivity, labour flexibility, and capital efficiency.

Dharmaraj and Kathirvel (2013), the Indian Automobile Industry marked a new journey in the 1991 with the financial revolutionary New Industrial Policy Act 1991, opening automatic route which allowed the 100 per cent Foreign Direct Investment(FDI). Here, an attempt is made to find out the effect of FDI on the financial performance of Indian Automobile Industry. For this purpose, sixteen companies were selected and analysed through various financial ratios. Descriptive statistical tools like Mean, Standard Deviation and Student's paired ' $t$ ' Test were used to test the hypothesis. The liquidity analysis showed little changes and profitability analyses showed an increasing trend during post FDI when compared to pre FDI. The efficiency analysis showed that the companies are efficiently utilizing the available resources during post FDI as compared to pre FDI. It is concluded that foreign direct investment in India makes positive impact on the financial variables of the Automobile Companies.

\section{Profitability Ratios: \\ The Profitability ratios measures the overall performance and effectiveness of the firm. GROSS PROFIT RATIO}

Gross profit ratio is the ratio of gross profit to net sales i.e. sales less sales returns. The ratio thus reflects the margin of profit that a concern is able to earn on its trading and manufacturing activity. It is the most commonly calculated ratio. It is employed for inter-firm and inter-firm comparison of trading results. Gross profit is what is revealed by the trading account. It results from the difference between net sales and cost of goods sold without taking into account expenses generally charged to the profit and loss account. The larger the gap, the greater is the scope for absorbing various expenses on administration, maintenance, arranging finance, selling and distribution and yet leaving net profit for the proprietors or shareholders. 


\subsection{GROSS PROFIT RATIO}

Gross profit $=$ Gross profit $/($ Net sales $\times 100)$

\begin{tabular}{|c|c|c|c|}
\hline Year & Gross Profit & Sales & Ratio \\
\hline $2010-2011$ & 11718.6 & 36618.4 & 32 \\
\hline $2011-2012$ & 14678.3 & 35587.1 & 41.24 \\
\hline $2012-2013$ & 19633.9 & 43587.9 & 45.04 \\
\hline $2013-2014$ & 22435 & 43700.6 & 51.33 \\
\hline $2014-2015$ & 26076.9 & 49970.6 & 52.18 \\
\hline
\end{tabular}

Source: Computed

\section{INFERENCE:}

The above table shows the Gross Profit Ratio position of the Maruti Suzuki India. The Gross Profit Ratio was ranges from32 to 52.18 during the study period 2010-11 to 2014-15.

\section{GROSS PROFIT RATIO}

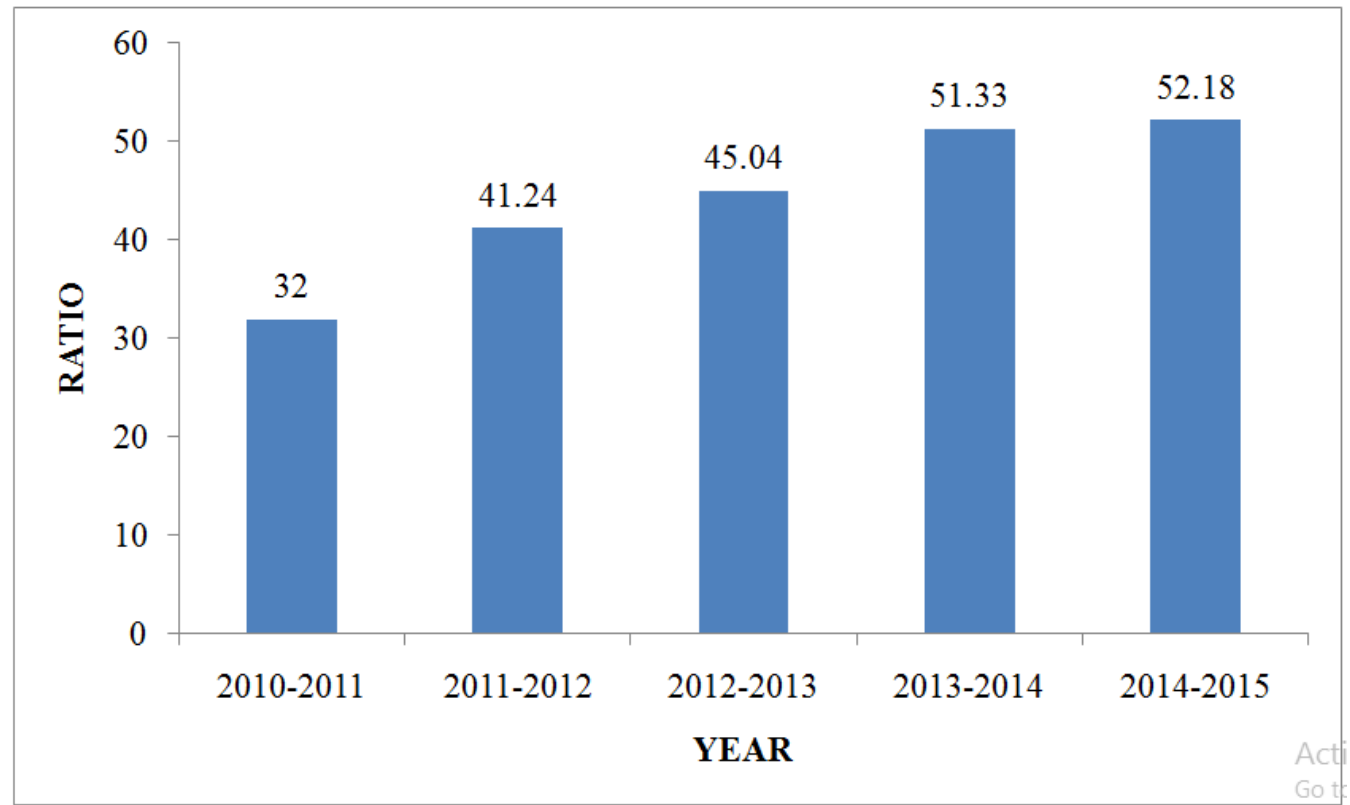

\subsection{NET PROFIT RATIO}

Net profit ratio (NP ratio) expresses the relationship between net profit after taxes and sales. This ratio is a measure of the overall profitability net profit is arrived at after taking into account both the operating and non-operating items of incomes and expenses. The ratio indicates what portion of the net sales is left for the owners after all expenses have been met.

\subsection{Net profit ratio}

Net profit $=$ Net profit $/$ sales $* 100$

\begin{tabular}{|c|c|c|c|}
\hline Year & Net Profit & Sales & Ratio \\
\hline $2010-2011$ & 2288.6 & 36618.4 & 63.24 \\
\hline $2011-2012$ & 1635.2 & 35587.1 & 4.60 \\
\hline $2012-2013$ & 2392.1 & 43587.9 & 5.49 \\
\hline $2013-2014$ & 2783 & 43700.6 & 6.37 \\
\hline $2014-2015$ & 3711.2 & 49970.6 & 7.43 \\
\hline
\end{tabular}

Source: Computed

INFERENCE:

The above table shows the Net profit ratio of the Maruti Suzuki india Limited. The Net profit ratio was ranges from 63.24 to 7.43 during the study period 2010-11 to 2014-15. 


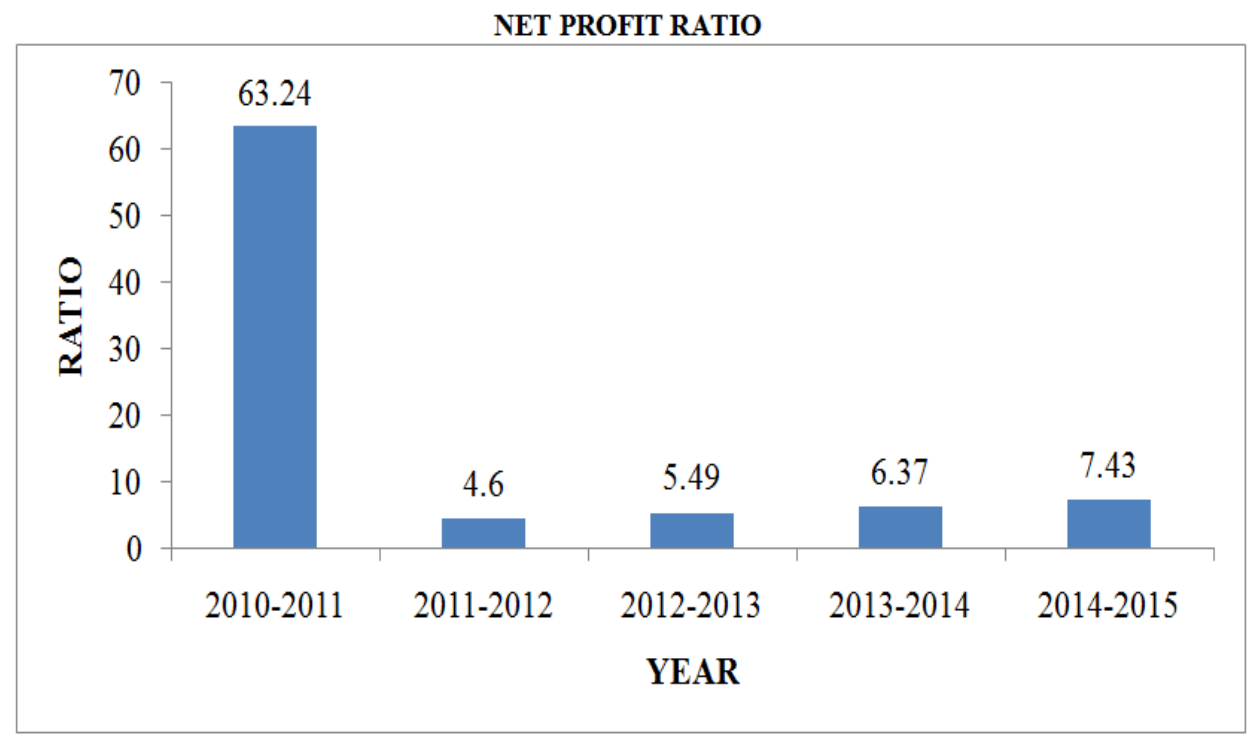

\subsection{OPERATING RATIO}

The operating ratio is a financial term defined as a company's operating expenses as a percentage of revenue. This financial ratio is most commonly used for industries which require a large percentage of revenues to maintain operations, such as railroads. In railroading, an operating ratio of 80 or lower is considered desirable. The operating ratio can be used to determine the efficiency of a company's management by comparing operating expenses to net sales. It is calculated by dividing the operating expenses by the net sales. The smaller the ratio, the greater the organization's ability to generate profit. The ratio does not factor in expansion or debt repayment. Alternatively, it may be expressed as a ratio of sales to cost. In such case a higher ratio indicates a better ability to generate revenue.

\subsection{OPERATING PROFIT RATIO}

Operating ratio $=$ operating ratio $/$ sales $* 100$

\begin{tabular}{|c|c|c|c|}
\hline Year & Operating Profit & Sales & Ratio \\
\hline $2010-2011$ & 3638.5 & 36618.4 & 9.94 \\
\hline $2011-2012$ & 2513 & 35587.1 & 7.06 \\
\hline $2012-2013$ & 4229.6 & 43587.9 & 9.70 \\
\hline $2013-2014$ & 5095.9 & 43700.6 & 11.66 \\
\hline $2014-2015$ & 6712.9 & 49970.6 & 13.43 \\
\hline
\end{tabular}

Source: Computed

\section{INFERENCE:}

The above table shows the operating profit ratio position of the Maruti Suzuki India Limited. The operating profit ratio was range from 9.94 to 13.43 during the study period 2010-11 to 2014-15.

\section{OPERATING PROFIT RATIO}

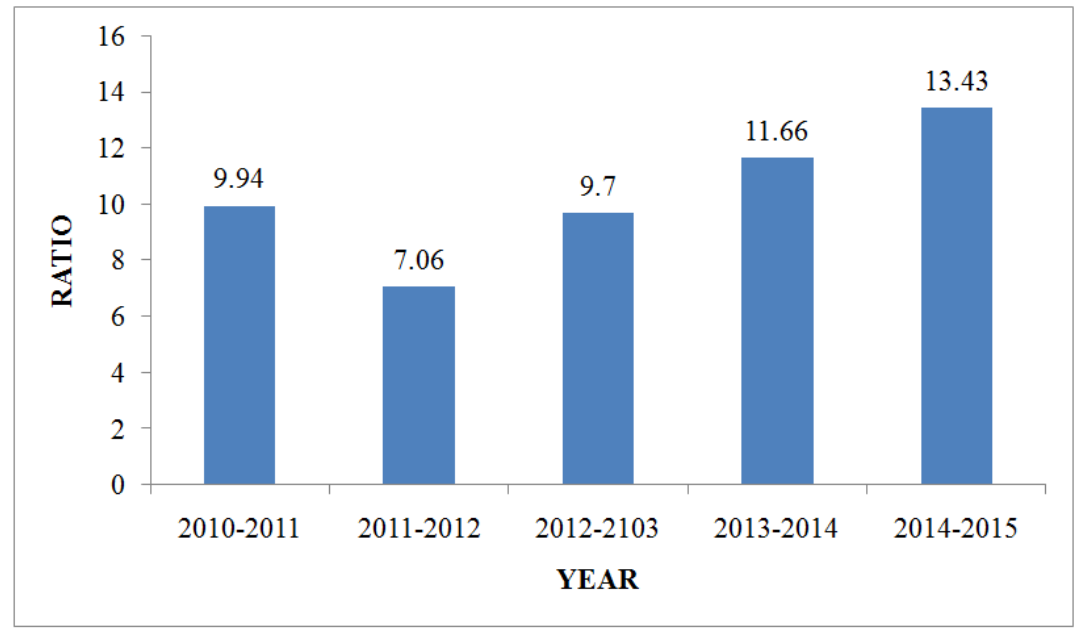




\subsection{PROPRIETARY RATIO}

The proprietary ratio (also known as the equity ratio) is the proportion of shareholders' equity to total assets, and as such provides a rough estimate of the amount of capitalization currently used to support a business. If the ratio is high, this indicates that a company has a sufficient amount of equity to support the functions of the business, and probably has room in its financial structure to take on additional debt, if necessary. Conversely, a low ratio indicates that a business may be making use of too much debt or trade payables, rather than equity, to support operations (which may place the company at risk of bankruptcy).

\section{PROPRIETORY RATIO}

Proprietary ratio $=$ Shareholders fund $/$ Total tangible assets

\begin{tabular}{|c|c|c|c|}
\hline Year & Shareholders' funds & Total Tangible Assets & Ratio \\
\hline $2010-2011$ & 13867.5 & 14037.7 & 0.98 \\
\hline $2011-2012$ & 15187.4 & 16265.7 & 0.93 \\
\hline $2012-2013$ & 18578.9 & 19968.1 & 0.93 \\
\hline $2013-2014$ & 20978 & 22663.1 & 0.92 \\
\hline $2014-2015$ & 23704.2 & 23884.4 & 0.99 \\
\hline
\end{tabular}

Source: Computed

INFERENCE:

The above table shows the proprietary ratio position of the Maruti Suzuki India Limited. The proprietary ratio was ranges from 0.98 to 0.99 during the study period 2010-11 to 2014-15.

\section{PROPRIETORY RATIO}

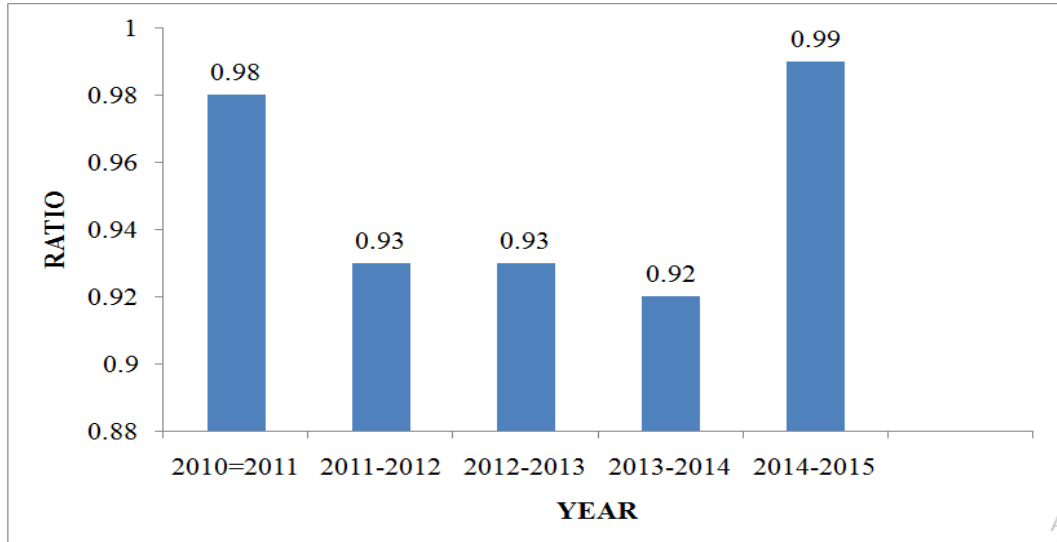

\section{ACTIVITY RATIOS}

Activity ratios reflect the firm's efficiency in utilizing its assets.

\subsection{ASSETS TURNOVER RATIO}

Asset turnover is a financial ratio that measures the efficiency of a company's use of its assets in generating sales revenue or sales income to the company. Companies with low profit margins tend to have high asset turnover, while those with high profit margins have low asset turnover. Companies in the retail industry tend to have a very high turnover ratio due mainly to cutthroat and competitive pricing. The ratio of the value of a company's sales or revenues generated relative to the value of its assets. The Asset Turnover ratio can often be used as an indicator of the efficiency with which a company is deploying its assets in generating revenue.

\section{ASSETS TURNOVER RATIO}

Total asset turnover ratio $=$ Sales $/$ Net Assets

\begin{tabular}{|c|c|c|c|}
\hline Year & Sales & Net Assets & Ratio \\
\hline $2010-2011$ & 36618.4 & 14037.7 & 2.60 \\
\hline $2011-2012$ & 35587.1 & 16265.7 & 2.19 \\
\hline $2012-2013$ & 43587.9 & 19968.1 & 2.18 \\
\hline $2013-2014$ & 43700.6 & 22663.1 & 1.92 \\
\hline $2014-2015$ & 49970.6 & 23884.4 & 2.09 \\
\hline
\end{tabular}

\section{Source: Computed}




\section{INFERENCE:}

The above table shows the Assets Turnover Ratio position of the Maruti Suzuki India Limited . The Assets Turnover Ratio ranges from 2.60 to 2.09 during the study period 2010-11 to 2014-15.

\section{ASSETS TURNOVER RATIO}

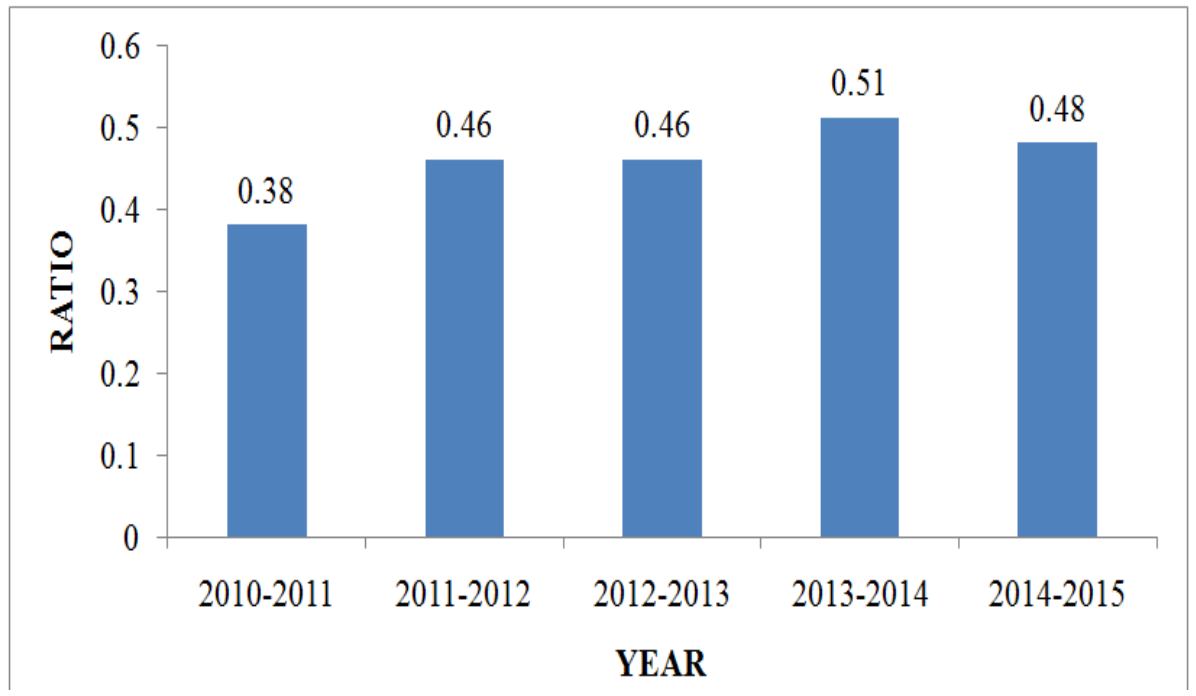

\subsection{STOCK TURNOVER RATIO ( INVENTORY TURNOVER RATIO)}

The Inventory turnover is a measure of the number of times inventory is sold or used in a time period such as a year. The equation for inventory turnover equals the cost of goods sold or net sales divided by the average inventory. Inventory turnover is also known as inventory turns, merchandise turnover, stock turn, stock turns, turns, and stock turnover.

- Increasing inventory turns reduces holding cost. The organization spends less money on rent, utilities, insurance, theft and other costs of maintaining a stock of good to be sold.

- $\quad$ Reducing holding cost increases net income and profitability as long as the revenue from selling the item remains constant.

- Items that turn over more quickly increase responsiveness to changes in customer requirements while allowing the replacement of obsolete items. This is a major concern in fashion industries.

- When making comparison between firms, it's important to take note of the industry, or the comparison will be distorted. Making comparison between a supermarket and a car dealer, will not be appropriate, as supermarket sells fast moving goods such as sweets, chocolates, soft drinks so the stock turnover will be higher. However, a car dealer will have a low turnover due to the item being a slow moving item. As such only intra-industry comparison will be appropriate.

\section{STOCK TURNOVER / INVENTORY RATIO}

Stock turnover ratio $=$ Cost of goods sold $/$ Inventory

\begin{tabular}{|c|c|c|c|}
\hline Year & Cost of goods sold & Inventory & Ratio \\
\hline $\mathbf{2 0 1 0 - 2 0 1 1}$ & 36618.4 & 1303.35 & 28.09 \\
\hline $2011-2012$ & 35587.1 & 2472.3 & 14.39 \\
\hline $2012-2013$ & 49090 & 203.1 & 241.70 \\
\hline $2013-2014$ & 48878.6 & 97.35 & 502.09 \\
\hline $2014-2015$ & 55133.6 & 44 & 1253.03 \\
\hline
\end{tabular}

\section{Source: Computed}

\section{INFERENCE:}

The above table shows the Stock Turnover / Inventory Ratioposition of the Maruti Suzuki India Limited. The Stock Turnover / Inventory Ratio ranges from 28.09 to 1253.03 during the study period for the study period 2010-11 to 2014-15. 


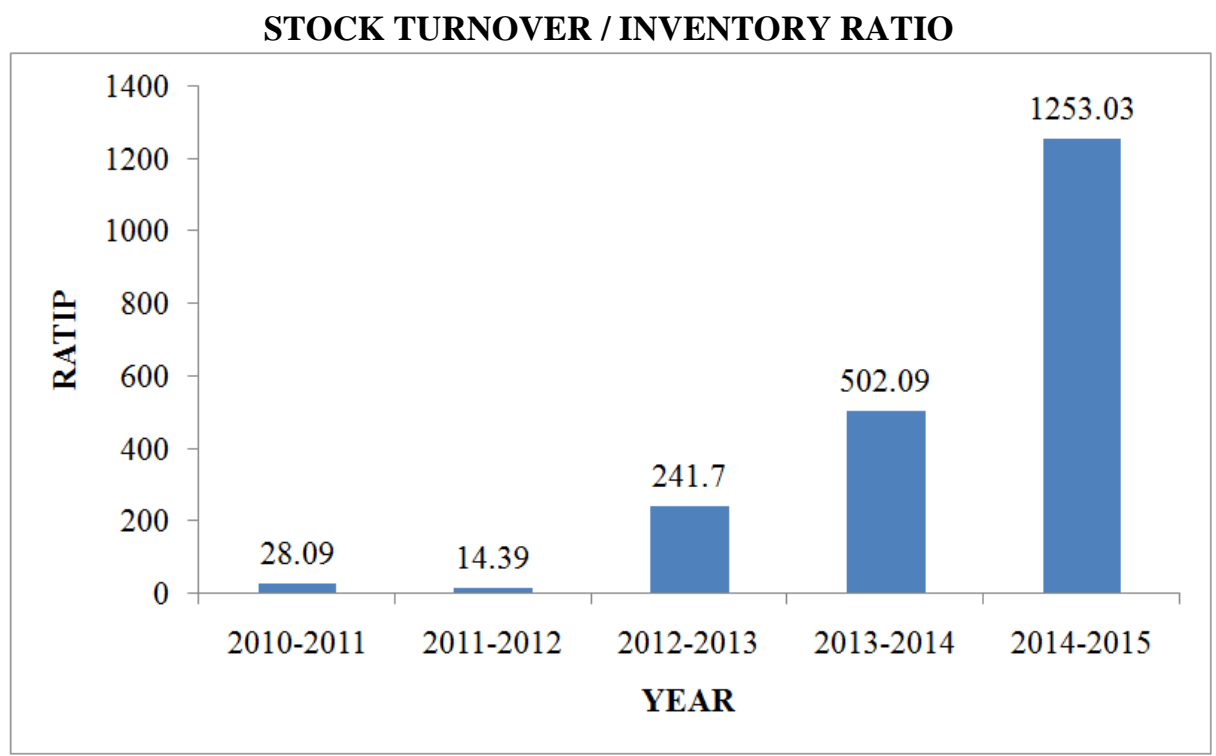

\section{Summary Of Findings, Suggestions And Conclusions}

Performance of a company measured in financial terms, the success of the firm depends on how it is perceived by and reacts to the external economics markets. The field of managing fiancé is much more complicated and faster faces today. Financial managers need to know how effective decisions can be made and ineffective ones be avoided. The present study is concerned with financial analysis of Maruti Suzuki India Limited for a period of five years during 2010-11 to 2014-15. This chapter optimizes the major findings, suggestions and conclusions for efficient utilization with respect to Maruti Suzuki India Limited Company.

\section{Findings}

$>$ The current ratio was increased the ratio of 1.09 in the year 2010-2011 and decreased 0.38 in the year 20142015

$>$ The Liquid Ratio was increased in the ratio of 0.76 in the year 2010-2011 and decreased 0.11 in the year 2014-2015

$>$ The Absolute liquid ratio was increased in the ratio of 1.89 in the year 2014-2015 and decreased 0.07 in the year 2013-2014

$>$ The Gross Profit Ratio was increased in the ratio of 52.18 in the year 2014-2015 and decreased 32 in the year 2010-2011

$>$ The Net profit ratio was increased in the ratio of 63.24 in the year 2010-2011 and decreased 4.60 in the year 2011-2012

$>$ The operating profit ratio was increased in the ratio of 13.43 in the year 2014-2015 and decreased 7.06 in the year 2011-2012

$>$ The Debt - Equity Ratio balanced in the ratio of $100 \%$ all the year.

$>$ The Proprietary ratio was increased in the ratio of 0.99 in the year 2014-2015 and decreased 0.92 in the year 2013-2014

$>$ The Total Assets Turnover Ratio was increased in the of 0.51 in the year 2013-2014 and decreased 0.38 in the year 2010-2011

> The Stock Turnover / Inventory Ratio was increased in the ratio of 1253.03 in the year 2014-2015 and decreased 14.39 in the year 2011-2012

\section{Suggestions}

Auto industry thus present a good opportunity for the investors especially in the form of Mahindra and Mahindra Itd. Major Indian producers like Tata's and Maruti may be doing good in the form of numbers in sales but will face great competition in for of Mahindra and Mahindra. Mahindra and Mahindra has a great position on the stock market and will attract investors and this could lead to expansion and growth. Thus the Tata's and Maruti need to take care of their stock and work on its consistency. This would help them attract more investors and grow in this growing economy of India. Increasing demands and sales numbers of Indian auto bring many opportunities for these players if they are up to grab it. 


\section{Conclusions}

The study explored the truth that ratios by themselves mean nothing. It is found that ratios are calculated from the financial statements' which are prepared as desired by the management and policies adopted on depreciation and stock values and thus produce only a collection of facts expressed in monetary term and cannot produce complete and authentic picture of the business and also may not highlight other factors which affects performance. It is also found that to control manager's management often overuse ratio and concentrate more on improving the ratios. It is also known fact that ratio is simple comparison of numerator and a denominator and in comparing ratios it become difficult to adjudicate whether differences are due to change in the numerator or denominator or in both. It is also found that ratios are interconnected but are often treated by management in isolation. It is also found that analysis of ratios lack authenticity as data used in calculation are not accurate but manipulated presentation by the promoters. It is also found that different firms follow different accounting policies like depreciation allowance; valuation of inventory etc. and often management ignore these differences while making inter-firm comparison. It is known fact that ratios are calculated from past records and have no indicator of future and are also not compared according to standard. It is also found that change in price levels due to inflation is also not properly considered by management. In the shadow of above revelation and fact the study conclude that Marutisuzuki have better strategic position in comparison to its competitor in all the respective ratios. It has secured top position in Liquidity analysis, in profitability analysis in relation to sales and in relation to investment, in efficiency analysis, in leverage analysis, in market valuation and has secured first rank. Tata on other hand with almost second rank in all the respective analysis has secured second position.

\section{References}

[1] Agarwal, M.P., Analysis of Financial Statements, National Publishing House, New Delhi, 1981, p.5.

[2] Batty, Management accounting, McConald and Evens Ltd., 1970, p.143

[3] Gupta.S.P. Statistical Methods, Sultan Chand \& Sons, New Delhi (2005)

[4] Dr. KhankaS.S., Entrepreneurial Development, S. Chand \& Co Pvt Ltd., pp.51-66

[5] Panday.I.M., Elements of financial Management, Vikas Publishing House Pvt Ltd., 1993, pp.1-21

IOSR Journal of Business and Management (IOSR-JBM) is UGC approved Journal with S1. No. 4481, Journal no. 46879.

Dr.A. Ramya. "A Study on Financial Analysis of Maruthi Suzuki India Limited Company ." IOSR Journal of Business and Management (IOSR-JBM) 19.7 (2017): 93-101. 